\title{
PENGEMBANGAN LKS UNTUK MELATIH KEMAMPUAN BERPIKIR KRITIS DALAM MATA PELAJARAN MATEMATIKA DI KELAS VII SMP
}

\author{
Puji Astuti $^{1}$, Purwoko' ${ }^{2}$ Indaryanti ${ }^{3}$ \\ 1. p.astutipuji@gmail.com \\ Program Studi Pendidikan Matematika \\ FKIP - Universitas Sriwijaya \\ 2017
}

\begin{abstract}
Abstrak
Tujuan pembelajaran matematika adalah untuk melatih siswa berpikir kritis. Oleh karena itu, perlu dikembangkan Lembar Kerja Siswa (LKS) untuk melatih kemampuan berpikir kritis siswa. Penelitian ini bertujuan untuk menghasilkan LKS yang berkarakteristik untuk melatih kemampuan berpikir kritis siswa kelas VII SMP. Sampel pada penelitian ini adalah kelas VII7 berjumlah 30 siswa semester II SMP Negeri 9 Palembang. Metode penelitian yang digunakan adalah metode penelitian pengembangan yang terdiri dari analisis, desain, evaluasi dan revisi. Pengumpulan data dilakukan dengan cara prototyping. Prototyping dilakukan untuk mengetahui bagaimana karakteristik LKS untuk melatih kemampuan berpikir kritis siswa kelas VII SMP. Hasil penelitian ini adalah karakteristik LKS untuk melatih kemampuan berpikir kritis siswa kelas VII SMP.
\end{abstract}

Kata kunci: kemampuan berpikir kritis, lembar kerja siswa

\begin{abstract}
Mathematics learning aims to develop students' critical thinking. Therefore, it is necessary to develop Student Worksheet to train students' critical thinking skills. This research aims to develop student worksheet that has characteristics of critical thinking skill for 7th grade Junior High School students (SMP). The sample in this research was class VII7 with 30 students of the second semester of SMP Negeri 9 Palembang. The research method used is a development research method that consists of analysis, design, evaluation and revision. Data collection is done by prototyping. Prototyping was used to find out how the characteristics of student worksheet to develop critical thinking ability of grade 7 students. The result of this research is characteristic of student worksheet to develop critical thinking ability of 7th grade Junior High School student.
\end{abstract}

Keywords: critical thinking ability, student worksheet

\section{Pendahuluan}

Berpikir dikatakan kritis manakala si pemikir berusaha menganalisis informasi secara benar, cermat, mencari bukti yang sah, dan menghasilkan kesimpulan yang mantap untuk mempercayai dan melakukan sesuatu (Ennis, 1996; Fisher, 2009; Kurniawan, 2002). Melalui proses berpikir dengan kritis seseorang dapat memperoleh informasi dengan benar, mengevaluasinya dan memproses informasi 


\section{JURNAL GANTANG. September 2017; II(2): 145 - 155 \\ p-ISSN. 2503-0671 \\ e-ISSN. 2548-5547}

tersebut sehingga diperoleh suatu kesimpulan yang terpercaya. Dalam era persaingan global, kompetensi berpikir kritis di kalangan peserta didik merupakan kemampuan yang sangat esensial sebagai antisipasi dalam memilih dan memilah luapan informasi baru yang muncul tiap harinya. Dengan demikian, keterampilan berpikir kritis harus ditransformasikan melalui proses pendidikan (Somakim, 2011). Keterkaitan berpikir kritis dalam pembelajaran adalah perlunya mempersiapkan siswa agar menjadi pemecah masalah yang handal, pembuat keputusan yang matang, dan orang yang tak pernah berhenti belajar.

Salah satu program pendidikan yang dapat mengembangkan kemampuan berpikir kritis adalah matematika. Hakikat pendidikan matematika yaitu pengembangan kemampuan nalar dan logis, sistematis, kritis, dan cermat serta berpikir objektif dan terbuka (Sumarmo, 2004). Kemampuan berpikir kritis juga merupakan kompetensi hasil belajar matematika yang dituntut oleh kurikulum 2006. Dalam KTSP (Depdiknas, 2006) dan Peraturan Menteri Pendidikan Nasional No. 23 Tahun 2006 tentang Standar Kompetensi Lulusan, dikatakan bahwa mata pelajaran matematika perlu diberikan kepada semua peserta didik mulai dari sekolah dasar untuk membekali peserta didik dengan kemampuan berpikir logis, analitis, sistematis, kritis, dan kreatif, serta kemampuan bekerja sama. Dari uraian tentang kemampuan yang harus dimiliki peserta didik matematika serta urgensi kemampuan berpikir kritis di masa saat ini, lembaga pendidikan harus mempersiapkan siswanya untuk memiliki kemampuan berpikir kritis.

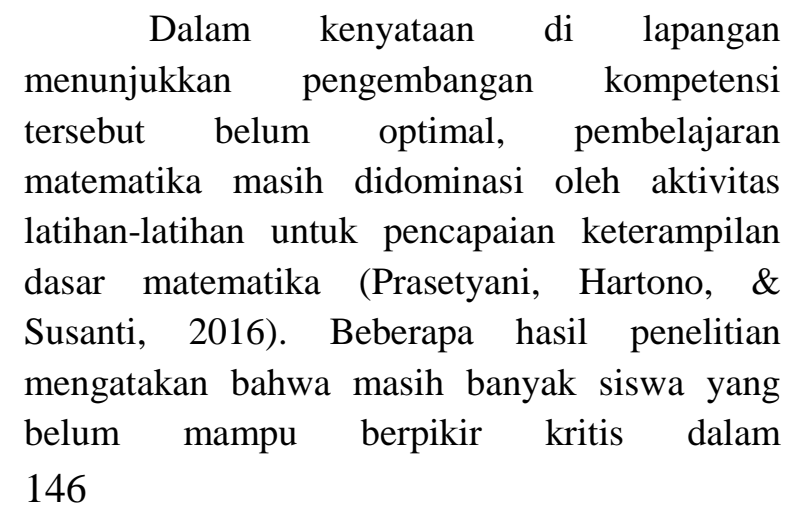

menyelesaikan masalah matematika (Rusiyanti, 2009). Indikasi dapat dilihat dari siswa yang umumnya lebih suka mengerjakan soal-soal yang sudah tahu prosedur perngerjaannya melalui contoh-contoh. Sedangkan latihan-latihan prosedural tidak terlalu banyak menuntut aktivitas berpikir anak sehingga kemampuan berpikir kritis mereka tidak berkembang. Berdasarkan hasil observasi peneliti terhadap siswa kelas VII7 SMP Negeri 9 Palembang didapat bahwa siswa kurang kritis dalam menyelesaikan masalah matematika. Hal ini juga didukung oleh informasi guru bahwa hanya sebagian siswa yang aktif terlibat bertanya dan berpikir kritis dalam proses pembelajaran.

Lemahnya kemampuan berpikir kritis siswa dapat disebabkan oleh faktor yang berkaitan dengan pembelajaran, misalnya metode pembelajaran matematika yang masih terpusat pada guru sehingga siswa cenderung pasif dan tidak mempunyai kesempatan untuk berpikir (Marsigit, 2000; Permanasari, 2013; Zulkardi, 2001). Kemampuan berpikir kritis siswa dapat berkembang dengan adanya kegiatan pembelajaran yang menggiring mereka untuk mencapai kompetensi tersebut, dimana siswa dapat terlibat aktif dalam proses berpikir matematis yang bermanfaat dan bermakna (Rusiyanti, 2009). Berdasarkan hasil wawancara peneliti dengan guru matematika SMP N 9 Palembang bahwa guru memancing berpikir kritis siswa hanya dengan mengajukan pertanyaan secara lisan pada proses pembelajaran. Sedangkan peneliti berpendapat bahwa dengan memberikan pertanyaan secara lisan saja tidak cukup untuk memancing siswa berpikir kritis sepenuhnya karena yang terlibat berpikir hanyalah beberapa siswa yang saat itu memperhatikan guru. Agar semua siswa terlibat aktif berpikir kritis maka guru harus mencari alternatif lain yang dapat memfasilitasi siswa untuk mengembangkan berpikir kritis. Salah satunya yaitu dengan penggunaan Lembar Kerja Siswa (LKS) dimana setiap siswa dapat menuangkan ide-ide dan pendapatnya dalam mengkritisi permasalahan matematika. Dengan 
demikian proses melatih berpikir kritis siswa akan lebih terarah dan menyeluruh.

LKS sangat baik digunakan untuk mengaktifkan keterlibatan siswa dalam belajar baik dipergunakan dalam penerapan pembelajaran maupun memberikan latihan pengembangan. Dengan LKS siswa dapat mengkonstruksi pengetahuan sehingga siswa dapat mengkritisi pelajaran dan dapat berperan aktif, tidak semata-mata mengerjakan latihanlatihan matematika yang bersifat algoritmik, mekanistik dan rutin. Tetapi guru menginformasikan bahwa LKS pernah dipakai pada tahun ajaran sebelumnya, tapi pada tahun ajaran ini LKS tidak dipakai lagi. Hal ini disebabkan atas pertimbangan kualitas LKS yang beredar tidak berubah dari tahun ke tahun, yang berubah hanya cover dan susunannya saja sedangkan isinya tetap sama, padahal kurikulum yang dipakai telah berubah. Maka sekolah memutuskan untuk tidak lagi memakai LKS yang beredar di pasaran. Zulkardi mengatakan diperlukan kecakapan guru untuk mengembangkan suatu media pembelajaran yang tepat, baik untuk materi ataupun situasi dan kondisi pembelajaran sehingga siswa memperoleh kompetensi yang diharapkan dan pembelajaran lebih bermakna. Media pembelajaran tersebut dapat berupa LKS, yang merupakan stimulus atau bimbingan guru dalam pembelajaran yang disajikan secara tertulis berupa informasi maupun soal-soal (pertanyaanpertanyaan) dan harus dijawab oleh siswa. Dalam proses pembelajaran matematika, LKS bertujuan untuk menemukan konsep atau prinsip dan aplikasi konsep atau prinsip. LKS dapat disesuaikan dengan kebutuhan siswa di kelas sehingga mempermudah siswa untuk menggali kemampuan berpikir kritisnya. Pada penelitian sebelumnya telah dilakukan usaha pengembangan perangkat pembelajaran untuk melatih kemampuan berpikir kritis siswa melalui pembelajaran matematika berbasis konstruktivisme dan penggunaan LKS memiliki potensial efek terhadap kemampuan berpikir kritis siswa (Rusiyanti, 2009). Pada penelitian ini, peneliti tertarik untuk mengembangkan LKS yang dikembangkan berdasarkan indikator berpikir kritis dengan harapan dapat melatih kemampuan berpikir kritis siswa. Berdasar uraian di atas, peneliti bermaksud mengadakan penelitian dengan judul "Pengembangan LKS untuk Melatih Kemampuan Berpikir Kritis dalam Mata Pelajaran Matematika di Kelas VII SMP”. Dan pertanyaan penelitian ini adalah: Bagaimana karakteristik LKS untuk melatih kemampuan berpikir kritis dalam mata pelajaran matematika di kelas VII SMP? Penelitian ini bertujuan: Menghasilkan LKS yang berkarakteristik untuk melatih kemampuan berpikir kritis dalam mata pelajaran matematika di kelas VII SMP.

\section{Metode Penelitian \\ Penelitian Jenis Penelitian}

Penelitian ini menggunakan metode penelitian pengembangan yang bertujuan untuk menghasilkan LKS untuk melatih kemampuan berpikir kritis siswa. Populasi dalam penelitian ini adalah seluruh siswa kelas VII SMP Negeri 9 Palembang tahun ajaran 2009-2010. Sedangkan sampel penelitiannya diambil secara purposif, yaitu kelas VII7.

\section{Prosedur pengembangan perangkat pembelajaran}

Tahap-tahap yang harus dilakukan dalam penelitian dan pengembangan ada tiga tahapan, yaitu: tahap pendahuluan, tahap pengembangan, dan tahap evaluasi (Sugiyono, 2011). Dengan juga memperhatikan langkah-langkah pengembangan model Dick and Carey, maka penelitian ini menggunakan dua tahapan, yaitu tahap pendahuluan dan tahap pengembangan. Penelitian ini belum sampai pada tahap evaluasi sumatif atau pada tahap pengujian LKS ke beberapa sekolah karena penelitian ini hanya sampai uji coba untuk kalangan terbatas yaitu siswa kelas VII7 SMP Negeri 9 Palembang.

\section{Tahap Pendahuluan}

Tahapan ini meliputi:

a. Mengidentifikasi kemampuan dasar

Pada tahap ini hal yang dilakukan berupa identifikasi materi yang akan dibuatkan LKS untuk dapat melatih kemampuan berpikir kritis siswa yaitu materi garis dan sudut SMP kelas VII. Peneliti mengumpulkan informasi tentang 


\section{JURNAL GANTANG. September 2017; II(2): 145 - 155 \\ p-ISSN. 2503-0671 \\ e-ISSN. 2548-5547}

kurikulum yang digunakan di kelas VII SMP Negeri 9 Palembang, yaitu Kurikulum Tingkat Satuan Pendidikan (KTSP). Pengembangan LKS berpedoman pada Standar Kompetensi (SK) dan Kompetensi Dasar (KD) yang dijadikan tujuan pembelajaran umum sesuai dengan yang tercantum dalam KTSP.

b. Menganalisis materi

Pada tahap ini, peneliti melakukan analisis terhadap keterampilan-keterampilan yang dapat menunjang tercapainya kemampuan dasar. Penganalisisan ini merupakan bagian dari pencapaian tujuan pembelajaran. Proses ini menghasilkan identifikasi konsep, aturan atau informasi yang dibutuhkan siswa, atau identifikasi dari langkah-langkah dalam serangkaian prosedur yang harus diikuti untuk mencapai tujuan umum yaitu SK dan KD.

c. Mempersiapkan siswa

Dilakukan pengamatan terhadap siswa yang akan menerima pelajaran untuk mengetahui tingkat kemampuan berpikir kritis siswa sehingga dapat dijadikan bahan pertimbangan dalam penyusunan LKS.

d. Merumuskan indikator kemampuan dasar

Yaitu menguraikan tujuan umum menjadi indikator pencapaian belajar siswa.

e. Mengembangkan kriteria penilaian

Mempersiapkan alat penilaian yang digunakan untuk melihat ketercapaian tujuan pembelajaran yaitu tes. Dalam hal ini tes digunakan untuk mengukur kemampuan berpikir kritis siswa setelah berlangsungnya proses pembelajaran dengan menggunakan LKS yang dikembangkan oleh peneliti.

f. Mengembangkan strategi pembelajaran

Pemilihan kegiatan belajar siswa dengan menggunakan LKS untuk melatih berpikir kritis.

g. Mengembangkan dan memilih materi pembelajaran

Pemilihan materi yang akan dituangkan

dalam LKS dengan memperhatikan tujuan khusus pembelajaran yang disesuaikan untuk melatih kemampuan berpikir kritis siswa. Materi dan soal yang dituliskan dalam LKS dikembangkan dari materi-materi yang ada. Pada tahap ini, dihasilkan produk awal LKS atau disebut dengan draft prototipe pertama. Selanjutnya dilakukan evaluasi terhadap LKS untuk mendapatkan LKS yang efektif, langkah ini dilakukan pada tahap pengembangan.

\section{Tahap Pengembangan}

Pada tahap ini dilakukan pengembangan terhadap desain materi yang disajikan dalam LKS. Adapun langkah-langkah pengembangan tersebut meliputi:

a. Penyusunan evaluasi formatif

Pada tahap ini dilakukan pengumpulan data ditujukan untuk menghasilkan LKS untuk melatih kemampuan berpikir kritis. Data-data yang diperoleh tersebut dijadikan sebagai pertimbangan dalam merevisi LKS yang dikembangkan. Langkah evaluasi formatif dapat dilihat pada skema berikut:

\section{Expert review dan One-to-one}

- Expert review

Hasil desain pada draft prototipe pertama yang dikembangkan oleh peneliti diberikan pada pakar (expert review) yaitu dosen pembimbing, pakar, dan guru senior matematika untuk uji validasi mengenai ketepatan LKS yang ditujukan untuk kemampuan berpikir kritis siswa mencakup content, konstruk, dan bahasa. Indikator kemampuan berpikir kritis dalam penelitian ini diadaptasi dari indikator kemampuan berpikir kritis Ennis (Ennis, 1996).

Tabel 1. Karakteristik berpikir kritis yang Menjadi Fokus Prototyping

\begin{tabular}{|l|lr|}
\hline Isi & $\begin{array}{l}\mid \\
\text { (Content })\end{array}$ & Isi LKS berupa : \\
& kejelasan standar \\
& kompetensi, -adanya tujuan \\
& pembelajaran r yang \\
& operasional r \\
& ketepatan urutan penyajian, \\
& -sub pokok bahasan yang \\
& ada pada LKS terurut, \\
& ketepatan evaluasi, -soal- \\
& soal latihan sesuai dengan \\
& indikator yang ditentukan \\
& dan latihan soal bertujuan \\
& untuk melatih kemampuan \\
& berpikir kritis-. \\
\hline Konstruk & Penyusunan LKS mengacu \\
(Construct $)$ & pada karakteristik \\
\hline
\end{tabular}




\begin{tabular}{|c|c|}
\hline & $\begin{array}{l}\text { kemampuan berpikir kritis } \\
\text { FRISCO, yaitu : } \\
\text { - Focus (Fokus) } \\
\text { Soal pada LKS dirancang } \\
\text { agar siswa fokus terlebih } \\
\text { dahulu terhadap pertanyaan } \\
\text { untuk dapat menjawab soal } \\
\text { - Reason (Alasan) } \\
\text { Soal pada LKS dirancang } \\
\text { untuk siswa mengemukakan } \\
\text { alasan dari jawabannya } \\
\text { - Inference (Kesimpulan) } \\
\text { Soal pada LKS dirancang } \\
\text { agar siswa menyimpulkan } \\
\text { jawaban setelah melakukan } \\
\text { analisa } \\
\text { - Situation (Situasi) } \\
\text { Situasi soal atau inti } \\
\text { pertanyaan dapat dimengerti } \\
\text { oleh siswa } \\
\text { - Clarity (Kejelasan) } \\
\text { Soal menuntut siswa untuk } \\
\text { jelas terhadap masalah agar } \\
\text { kesimpulan yang ia jawab } \\
\text { benar } \\
\text { - Overview (Pemeriksaan } \\
\text { secara keseluruhan) } \\
\text { - Soal pada LKS meminta } \\
\text { siswa untuk mengecek } \\
\text { kembali jawabannya agar ia } \\
\text { yakin terhadap yang ia } \\
\text { simpulkan }\end{array}$ \\
\hline Bahasa & $\begin{array}{l}\text { - } \text { Rumusan kalimat } \\
\text { komunikatif. } \\
\text { - Kalimat menggunakan } \\
\text { bahasa yang baik dan } \\
\text { benar, serta sesuai EYD. } \\
\text { - Rumusan kalimat tidak } \\
\text { menimbulkan penafsiran } \\
\text { ganda atau salah pengertian. }\end{array}$ \\
\hline
\end{tabular}

Dari uji validasi ini, maka akan diketahui kelemahan LKS dan bagaimana karakteristik LKS untuk melatih kemampuan berpikir kritis siswa. Saran-saran dari pakar dijadikan dasar untuk merevisi LKS. Adapun saran atau masukan dari pakar untuk pengembangan LKS untuk melatih kemampuan berpikir kritis dan keputusan revisi disajikan dalam tabel berikut:

Tabel 2. Saran dan Keputusan Revisi dari Pakar untuk LKS

\begin{tabular}{|l|l|}
\hline Saran & Keputusan Revisi \\
\hline & \\
\hline
\end{tabular}

\section{- One-to-one Evaluation}

Pada tahap ini draft LKS prototipe pertama diujicobakan kepada siswa yang bukan target penelitian. Siswa diminta mengerjakan dan mengomentari LKS. Hasil uji coba dan tanggapan siswa dianalisis dan dibahas apakah siswa mengalami kendala dalam memahami apa yang disajikan dalam LKS, sehingga dapat dijadikan masukan untuk revisi selanjutnya dan mengetahui bagaimana karakteristik LKS untuk melatih kemampuan berpikir kritis siswa.

\section{Small group}

Hasil revisi dari evaluasi expert review dan one-to-one, saran-saran serta hasil pekerjaan siswa dijadikan dasar untuk merevisi LKS sebagai draft prototipe kedua. Prototipe ini kemudian diujicobakan pada kelompok kecil (small group) yang bukan target penelitian terdiri dari 5 orang siswa yang memiliki karakteristik yang sama dengan karakteristik siswa yang akan dijadikan sasaran penelitian. Siswa juga akan diberikan tes untuk mengetahui tingkat kemampuan berpikir kritisnya. Berdasarkan hasil uji coba ini, dicatat kekurangan-kekurangan untuk revisi dan perbaikan mengenai bagaimana karakteristik LKS untuk melatih kemampuan berpikir kritis siswa.

\section{Field test}

Dari hasil uji small group, LKS direvisi lagi. Hasil revisi ini dijadikan sebagai draft prototipe ketiga yang kemudian diujicobakan ke lapangan (field test) yaitu subjek penelitian (siswa kelas VII SMP Negeri 9 Palembang). Peneliti mengobservasi kegiatan mereka selama proses pembelajaran untuk mengetahui kepraktisan LKS yang digunakan untuk melatih kemampuan berpikir kritis. Pada akhir pertemuan, peneliti melakukan evaluasi kepada siswa untuk mengetahui tingkat kemampuan berpikir kritis siswa setelah belajar dengan menggunakan LKS. Dari hasil tes tersebut dapat diketahui karakteristik apa saja yang memenuhi untuk LKS melatih kemampuan berpikir kritis siswa. Hasil dari tahap field test ini dianggap sebagai prototipe ketiga atau hasil akhir yang valid sebagai LKS pembelajaran materi garis dan 


\section{JURNAL GANTANG. September 2017; II(2): 145 - 155 \\ p-ISSN. 2503-0671 \\ e-ISSN. 2548-5547}

sudut untuk melatih kemampuan berpikir kritis siswa.

b. Perbaikan Pembelajaran

Penyimpulan data dari berbagai evaluasi formatif diperbaiki oleh peneliti sehingga kendala yang dialami dalam pembelajaran diperbaiki.

\section{Metode Pengumpulan Data}

Teknik pengumpulan data yang digunakan dalam penelitian ini adalah prototyping (validasi, evaluasi, dan revisi). Prosedur yang dilakukan yaitu peneliti memberikan prototipe LKS pada pakar yaitu dosen dan guru matematika untuk uji validasi lalu hasil evaluasi materi pada LKS berupa saran dijadikan untuk perbaikan terhadap LKS. Dalam pelaksanaan untuk mengumpulkan data bahan revisi digunakan checklist dan saran secara umum pada lembar validasi. Saran menyangkut content, konstruk dan bahasa sehingga dapat diketahui bagaimana karakteristik LKS untuk melatih kemampuan berpikir kritis dan dapat dinyatakan bahwa LKS valid. Adapun isi dari checklist pada lembar observasi dapat dilihat pada Tabel 1. Untuk mengetahui karakteristik LKS juga dilakukan dokumentasi hasil uji coba one to one dan uji coba small group.

\section{Metode Analisis Data}

Data yang dikumpulkan dianalisis dengan cara analisis data prototyping. Untuk menganalisis data validasi ahli, hasil uji coba one to one dan uji coba small group digunakan analisis deskriptif dengan cara merevisi berdasarkan wawancara ataupun catatan dari saran validator. Hasil dari analisis akan digunakan untuk merevisi LKS yang dibuat peneliti sehingga diketahui bagaimana karakteristik LKS untuk melatih kemampuan berpikir kritis.

\section{Hasil dan Pembahasan}

Penelitian ini dilaksanakan di SMP Negeri 9 Palembang. Sampel penelitian berjumlah 30 siswa yang memiliki intelegensi dan latar belakang yang sama sebagai sampel, yaitu VII7 dengan pembelajaran menggunakan
LKS untuk melatih kemampuan berpikir kritis. Data yang dianalisis adalah data prototyping LKS pada mata pelajaran matematika pokok bahasan hubungan antara dua garis dan jenis sudut.

Data prototipe mulai dari uji pakar, uji one to one, small group dilakukan self evaluation dan revisi untuk mengetahui bagaimana karakteristik LKS untuk melatih kemampuan berpikir kritis siswa dalam mata pelajaran matematika di kelas VII SMP. Saran-saran yang didapat pada tahap expert review dan one to one dievaluasi oleh peneliti untuk dijadikan acuan revisi produk. Evaluasi dan revisi LKS juga dilakukan setelah tahap uji coba small group. Sampai ke tahap field test didapat karakteristik final LKS untuk melatih kemampuan berpikir kritis siswa. Adapun karakteristik awal yang akan dianalisa melalui prototyping dapat dilihat pada Tabel 1 .

Prototipe Pertama

\section{- Expert Review}

Evaluasi expert review memberikan masukan mengenai validitas isi, konstruk, dan bahasa. Adapun hasil evaluasi peneliti dari lima pakar mengenai karakteristik LKS yang dapat terpenuhi dapat dilihat pada tabel 3.Pada tahapan ini, banyak poin karakteristik LKS yang belum dapat terpenuhi. Hal ini bukan karena poin tersebut tidak dapat dijadikan karakteristik LKS untuk melatih kemampuan berpikir kritis siswa tetapi karena isi LKS yang dikembangkan oleh peneliti belum dapat memenuhinya. Adapun kesalahan yang dibuat peneliti yaitu : -evaluasi soal yang terdapat pada LKS masih ada yang tidak sesuai dengan indikator yang ditentukan-, terdapat soal-soal latihan yang siswa tidak diarahkan untuk fokus ke gambar-, -latihan soal belum memfasilitasi siswa untuk mengemukakan alasan-, -situasi soal masih banyak yang tidak jelas dikarenakan kalimat yang membingungkan dan tidak komunikatif-, -belum terdapat soal yang menuntut siswa untuk memeriksa kembali jawaban-, -kekeliriuan mengenai materi pada penanaman konsep-. Kesalahan yang dibuat peneliti dapat dilihat pada gambar 1 dan 2 . 
Tabel 3. Karakteristik LKS pada Tahap Expert Review

\begin{tabular}{|c|l|c|}
\hline \multirow{4}{*}{$\begin{array}{c}\text { Isi } \\
\text { (Content) }\end{array}$} & kejelasan standar kompetensi, -adanya tujuan pembelajaran yang operasional- & $\checkmark$ \\
\hline & ketepatan urutan penyajian, -sub pokok bahasan yang ada pada LKS terurut & $\checkmark$ \\
\hline & $\begin{array}{l}\text { ketepatan evaluasi, -soal-soal latihan sesuai dengan indikator yang ditentukan } \\
\text { dan latihan soal bertujuan untuk melatih kemampuan berpikir kritis- }\end{array}$ & \\
\hline \multirow{5}{*}{ Konstruk } & $\begin{array}{l}\text { Focus (Fokus) } \\
\text { Soal pada LKS dirancang agar siswa fokus terlebih dahulu terhadap pertanyaan } \\
\text { untuk dapat menjawab soal }\end{array}$ & \\
\hline \multirow{5}{*}{ (Construct) } & $\begin{array}{l}\text { Reason (Alasan) } \\
\text { Soal pada LKS dirancang untuk siswa mengemukakan alasan dari jawabannya }\end{array}$ & \\
\hline & $\begin{array}{l}\text { Inference (Kesimpulan) } \\
\text { Soal pada LKS dirancang agar siswa menyimpulkan jawaban setelah analisis }\end{array}$ & $\checkmark$ \\
\hline & $\begin{array}{l}\text { Situation (Situasi) } \\
\text { Situasi soal atau inti pertanyaan dapat dimengerti oleh siswa }\end{array}$ & \\
\hline & $\begin{array}{l}\text { Kejelasan (Clarity) } \\
\text { Soal menuntut siswa untuk jelas terhadap masalah agar kesimpulan yang ia } \\
\text { jawab benar }\end{array}$ & $\checkmark$ \\
\hline & $\begin{array}{l}\text { Overview (Pemeriksaan secara keseluruhan) } \\
\text { Soal pada LKS meminta siswa untuk mengecek kembali jawabannya agar ia } \\
\text { yakin terhadap yang ia simpulkan }\end{array}$ & \\
\hline \multirow{3}{*}{ Bumusan kalimat komunikatif. } & \\
\hline & Kalimat menggunakan bahasa yang baik dan benar, serta sesuai EYD. & \\
\hline & Rumusan kalimat tidak menimbulkan penafsiran ganda atau salah pengertian. & \\
\hline
\end{tabular}
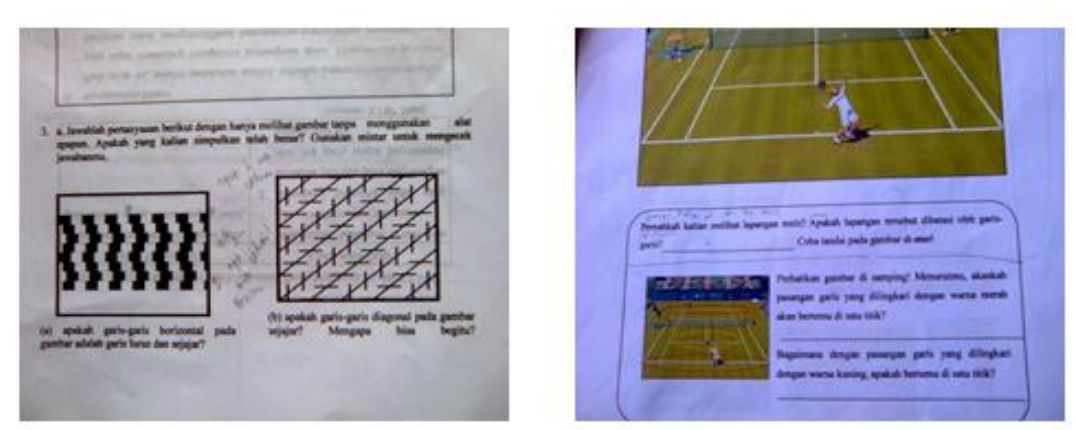

Gambar 1. Tampilan Materi Sebelum Direvisi I
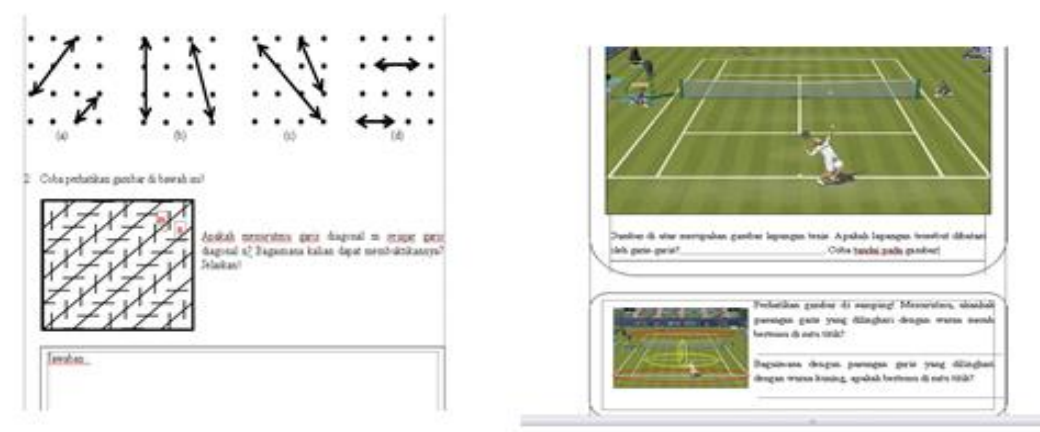

Gambar 2. Tampilan Materi Setelah Revisi I 


\section{JURNAL GANTANG. September 2017; II(2): 145 - 155 \\ p-ISSN. 2503-0671 \\ e-ISSN. 2548-5547}

\section{- One to One}

Seorang siswa memberikan tanggapan dan komentarnya terhadap materi yang ada pada LKS sehingga diketahui apakah siswa dapat memahami materi yang dibuat atau kesulitan apa yang siswa alami dalam memahami maateri yang disajikan dalam LKS. Peneliti juga mengevaluasi LKS hasil pekerjaan siswa guna mengetahui karakteristik LKS untuk melatih berpikir kritis yang dapat terpenuhi. Hasil evaluasi disajikan dalam tabel 4.

Pada tahapan ini juga banyak poin karakteristik LKS yang belum dapat terpenuhi. Masalah terjadi karena LKS yang dikembangkan peneliti belum sepenuhnya menuntun siswa agar karakteristik dapat dimunculkan semua. Adapun kesalahan yang dibuat peneliti yaitu pertanyaan yang dikembangkan belum memfasilitasi siswa untuk dapat memunculkan karakteristik berpikir kritis FRISCO. Gambaran kesalahan dapat dilihat pada gambar 3 dan 4 .

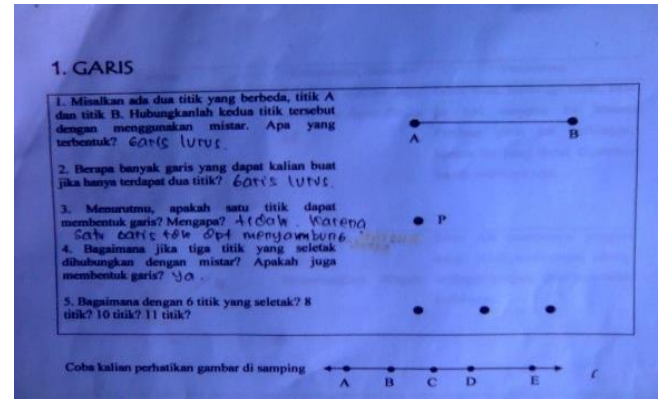

Gambar 3. Materi Sebelum Revisi II

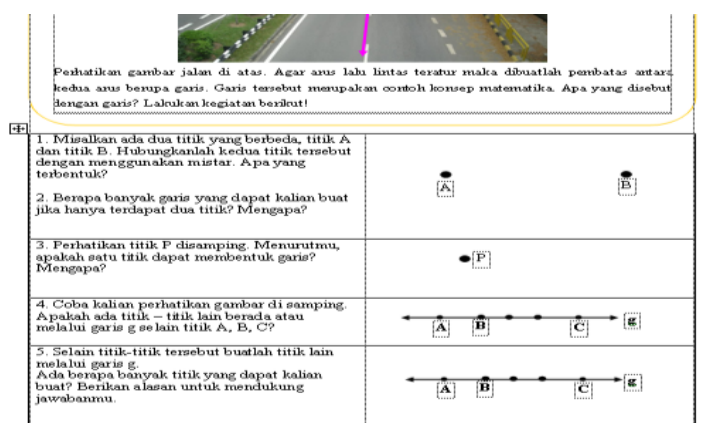

Gambar 4. Materi Setelah Revisi II

Hasil revisi dari evaluasi expert review dan one to one, saran-saran serta hasil pekerjaan siswa kemudian diujicobakan pada kelompok kecil (small group) yang bukan target penelitian terdiri dari 5 orang siswa yang memiliki karakteristik yang sama dengan karakteristik siswa yang akan dijadikan sasaran penelitian.

\section{Prototipe Kedua}

\section{- Small Group}

Hasil dari tanggapan siswa dan para ahli dari langkah terdahulu diperbaiki kemudian diujicobakan pada kelompok kecil. Masukan dari siswa berupa informasi dapat digunakan atau tidak LKS yang telah dikembangkan untuk melatih berpikir kritis. Adapun karakteristik LKS yang dapat terpenuhi pada tahapan ini disajikan dalam tabel 5.

Dari pekerjaan siswa di LKS dapat dilihat bahwa tahapan ini lebih baik dari tahapan sebelumnya. Poin-poin karakteristik LKS untuk melatih kemampuan berpikir kritis hampir seluruhnya terpenuhi, LKS sudah dapat memfasilitasi siswa untuk memunculkan enam karakteristik berpikir kritis FRISCO walau masih ada beberapa pertanyaan yang kalimatnya masih membingungkan siswa.

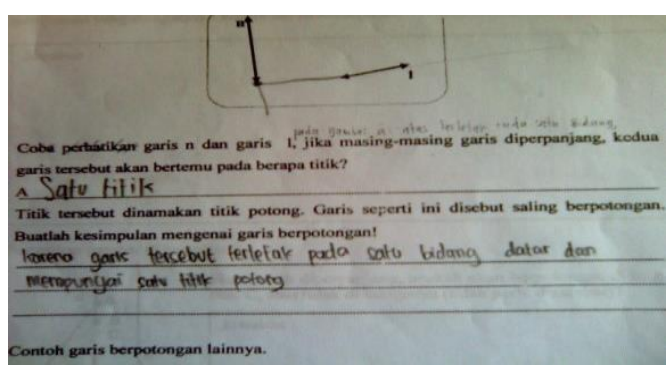

Gambar 5. Pekerjaan Siswa pada Tahap Small Group

\section{Prototipe Ketiga}

Hasil dari tahapan uji coba small group kemudian dievaluasi dan direvisi kembali oleh peneliti untuk diujicobakan ke tahapan field test. Peneliti mengevaluasi pekerjaan siswa pada LKS mengenai poin karakteristik yang dapat dipenuhi pada tahapan ini ditunjukkan dalam tabel 6 .

Dari analisis data prototyping, disimpulkanlah karakteristik LKS yang valid dan praktis untuk melatih kemampuan berpikir kritis siswa dalam mata pelajaran matematika di kelas VII SMP. 
Tabel 4. Karakteristik LKS pada Tahap One to One

\begin{tabular}{|c|c|c|}
\hline \multirow{3}{*}{$\begin{array}{c}\text { Isi } \\
\text { (Content) }\end{array}$} & kejelasan standar kompetensi, -adanya tujuan pembelajaran yang operasional- & $\checkmark$ \\
\hline & ketepatan urutan penyajian, -sub pokok bahasan yang ada pada LKS terurut & $\checkmark$ \\
\hline & $\begin{array}{l}\text { ketepatan evaluasi, -soal-soal latihan sesuai dengan indikator yang ditentukan } \\
\text { dan latihan soal bertujuan untuk melatih kemampuan berpikir kritis- }\end{array}$ & \\
\hline \multirow{6}{*}{$\begin{array}{l}\text { Konstruk } \\
\text { (Construct) }\end{array}$} & $\begin{array}{l}\text { Focus (Fokus) } \\
\text { Soal pada LKS dirancang agar siswa fokus terlebih dahulu terhadap pertanyaan } \\
\text { untuk dapat menjawab soal }\end{array}$ & $\checkmark$ \\
\hline & $\begin{array}{l}\text { Reason (Alasan) } \\
\text { Soal pada LKS dirancang untuk siswa mengemukakan alasan dari jawabannya }\end{array}$ & $\checkmark$ \\
\hline & $\begin{array}{l}\text { Inference (Kesimpulan) } \\
\text { Soal pada LKS dirancang agar siswa menyimpulkan jawaban setelah } \\
\text { melakukan analisa }\end{array}$ & $\checkmark$ \\
\hline & $\begin{array}{l}\text { Situation (Situasi) } \\
\text { Situasi soal atau inti pertanyaan dapat dimengerti oleh siswa }\end{array}$ & \\
\hline & $\begin{array}{l}\text { Kejelasan (Clarity) } \\
\text { Soal menuntut siswa untuk jelas terhadap masalah agar kesimpulannya benar }\end{array}$ & $\checkmark$ \\
\hline & $\begin{array}{l}\text { Overview (Pemeriksaan secara keseluruhan) } \\
\text { Soal pada LKS meminta siswa untuk mengecek kembali jawabannya agar ia } \\
\text { yakin terhadap yang ia simpulkan }\end{array}$ & \\
\hline \multirow{3}{*}{ Bahasa } & Rumusan kalimat komunikatif. & $\checkmark$ \\
\hline & Kalimat menggunakan bahasa yang baik dan benar, serta sesuai EYD. & \\
\hline & Rumusan kalimat tidak menimbulkan penafsiran ganda atau salah pengertian. & \\
\hline
\end{tabular}

Tabel 5. Karakteristik LKS pada Tahap Small Group

\begin{tabular}{|c|c|c|}
\hline \multirow{3}{*}{$\begin{array}{c}\text { Isi } \\
\text { (Content) }\end{array}$} & kejelasan standar kompetensi, -adanya tujuan pembelajaran yang operasional- & $\checkmark$ \\
\hline & ketepatan urutan penyajian, -sub pokok bahasan yang ada pada LKS terurut & $\checkmark$ \\
\hline & $\begin{array}{l}\text { ketepatan evaluasi, -soal-soal latihan sesuai dengan indikator yang ditentukan } \\
\text { dan latihan soal bertujuan untuk melatih kemampuan berpikir kritis- }\end{array}$ & $\checkmark$ \\
\hline \multirow{6}{*}{$\begin{array}{l}\text { Konstruk } \\
\text { (Construct) }\end{array}$} & $\begin{array}{l}\text { Focus (Fokus) } \\
\text { Soal pada LKS dirancang agar siswa fokus terlebih dahulu terhadap pertanyaan } \\
\text { untuk dapat menjawab soal }\end{array}$ & $\checkmark$ \\
\hline & $\begin{array}{l}\text { Reason (Alasan) } \\
\text { Soal pada LKS dirancang untuk siswa mengemukakan alasan dari jawabannya }\end{array}$ & $\checkmark$ \\
\hline & $\begin{array}{l}\text { Inference (Kesimpulan) } \\
\text { Soal pada LKS dirancang agar siswa menyimpulkan jawaban setelah } \\
\text { melakukan analisa }\end{array}$ & $\checkmark$ \\
\hline & $\begin{array}{l}\text { Situation (Situasi) } \\
\text { Situasi soal atau inti pertanyaan dapat dimengerti oleh siswa }\end{array}$ & $\checkmark$ \\
\hline & $\begin{array}{l}\text { Kejelasan (Clarity) } \\
\text { Soal menuntut siswa untuk jelas terhadap masalah agar kesimpulannya benar }\end{array}$ & $\checkmark$ \\
\hline & $\begin{array}{l}\text { Overview (Pemeriksaan secara keseluruhan) } \\
\text { Soal pada LKS meminta siswa untuk mengecek kembali jawabannya agar ia } \\
\text { yakin terhadap yang ia simpulkan }\end{array}$ & $\checkmark$ \\
\hline \multirow{3}{*}{ Bahasa } & Rumusan kalimat komunikatif. & $\checkmark$ \\
\hline & Kalimat menggunakan bahasa yang baik dan benar, serta sesuai EYD. & $\checkmark$ \\
\hline & siran & \\
\hline
\end{tabular}




\section{JURNAL GANTANG. September 2017; II(2): 145 - 155 \\ p-ISSN. 2503-0671 \\ e-ISSN. 2548-5547}

\section{Penutup}

Berdasarkan hasil penelitian dan pembahasan dapat disimpulkan sebagai berikut:

1. Karakteristik LKS untuk melatih kemampuan berpikir kritis siswa dalam mata pelajaran matematika di kelas VII SMP adalah:

Isi LKS berupa:

- Kejelasan standar kompetensi, -adanya tujuan pembelajaran yang operasional-, ketepatan urutan penyajian -sub pokok bahasan yang ada pada LKS terurut-,

- Ketepatan evaluasi, -soal-soal latihan sesuai dengan indikator yang ditentukan dan latihan soal bertujuan untuk melatih kemampuan berpikir kritis-.

Penyusunan soal dalam LKS mengacu pada karakteristik kemampuan berpikir kritis FRISCO, yaitu:

- Focus (Fokus)

Soal pada LKS dirancang agar siswa fokus terlebih dahulu terhadap pertanyaan untuk dapat menjawab soal

- Reason (Alasan)

Soal pada LKS dirancang untuk siswa mengemukakan alasan dari jawabannya

- Inference (Kesimpulan)

Soal pada LKS dirancang agar siswa menyimpulkan jawaban setelah melakukan analisa

- Situation (Situasi)

Situasi soal atau inti pertanyaan dapat dimengerti oleh siswa

- Kejelasan (Clarity)

Soal menuntut siswa untuk jelas terhadap masalah agar kesimpulan yang ia jawab benar

- Overview (Pemeriksaan secara keseluruhan)

Soal pada LKS meminta siswa untuk mengecek kembali jawabannya agar ia yakin terhadap yang ia simpulkan

Bahasa pada LKS:

- Rumusan kalimat komunikatif.

- Kalimat menggunakan bahasa yang baik dan benar, serta sesuai EYD.
- Rumusan kalimat tidak menimbulkan penafsiran ganda atau salah pengertian.

\section{Daftar Pustaka}

Depdiknas. (2006). Kurikulum Tingkat Satuan Pendidikan standar kompetensi SMP dan MTs. Jakarta: Depdiknas.

Ennis, R. H. (1996). Critical thinking. USA: Prentice Hall, Inc.

Fisher, A. (2009). Berpikir kritis sebuah pengantar. Jakarta: Erlangga.

Kurniawan. (2002). Pembudayaan keterampilan berpikir kritis di perguruan tinggi melalui cognitive coaching. Bandung: UPI.

Marsigit. (2000). Empirical evidence of Indonesian styles of primary teaching. Makalah Disajikan Di ICME Conference, Hiroshima Japan.

Permanasari, V. (2013). s pendekatan pembelajaran open-ended terhadap kemampuan berpikir matematis siswa pada materi trigonometri ditinjau dari kreativitas belajar matematika siswa. Jurnal Pendidikan Matematika Solusi, l(1).

Prasetyani, E., Hartono, Y., \& Susanti, E. (2016). Kemampuan berpikir tingkat tinggi siswa kelas XI dalam pembelaja ran trigonometri berbasis masalah di SMA Negeri 18 Palembang. Gantang, 1(1).

Rusiyanti, R. (2009). Pengembangan perangkat pembelajaran matematika berbasis konstruktivisme untuk melatih kemampuan berpikir kritis siswa SMA kelas $X$. PPs Unsri.

Somakim. (2011). Peningkatan kemamn- puan berpikir kritis matema- tis siswa sekolah menengah dengan penggunaan pendidikan matematika realistik. Jurnal Forum MIPA, 14(1).

Sugiyono. (2011). Metode penelitian kuantitatif, kualitatif dan $R \& D$. Jakarta: Alfhabeta.

Sumarmo. (2004). Kemandirian belajar apa, mengapa dan bagaimana dikembangkan pada peserta didik. In Seminar Pendidikan Matematika di Jurusan 
Pendidikan Matematika FMIPA,

Universitas Negeri Yogyakarta.

Yogyakarta: Universitas Negeri

Yogyakarta.

Syahbana, A. (2012). Peningkatan kemampuan berpikir kritis matematis siswa SMP melalui pembelajaran berbasis masalah melalui pendekatan Contextual Teaching and Learning. Edumatica, 2(1).

Zulkardi. (2001). Realistic mathematics education (RME): Teori, contoh pembelajaran, dan taman belajar di internet. Makalah disajikan dalam seminar sehari tentang Realistic Mathematics Education tanggal 4 April 2001. UPI: Tidak diterbitkan. 
JURNAL GANTANG. September 2017; II(2): 145 - 155

p-ISSN. 2503-0671

e-ISSN. 2548-5547 